\title{
APLIKASI THERMAL PRE-TREATMENT LIMBAH TANAMAN JAGUNG (Zea mays) SEBAGAI CO-SUBSTRAT PADA PROSES ANAEROBIK DIGESTI UNTUK PRODUKSI BIOGAS
}

\author{
Application of Thermal Pre-treatment on Corn Stover (Zea mays) as A Co-Substrate in Anaerobic \\ Digestion Process for Biogas Production
}

\author{
Darwin, Yusmanizar, Muhammad Ilham, Afrizal Fazil, Satria Purwanto, Sarbaini, Fatwa Dhiauddin \\ Jurusan Teknik Pertanian, Fakultas Pertanian, Universitas Syiah Kuala, \\ J1. Krueng Kalee, Darussalam, Banda Aceh, 23111 \\ Email: d4rwin_ae@yahoo.com
}

\begin{abstract}
ABSTRAK
Thermal pre-treatment diberikan pada limbah tanaman jagung dengan tujuan untuk memecahkan kandungan lignin yang terdapat pada limbah tanaman jagung sehingga memudahkan mikroorganisme anaerobik untuk mengkonversi polimer yang berupa selulosa dan hemiselulosa menjadi biogas. Tujuan dari penelitian ini adalah untuk melakukan kajian mengenai penerapan thermal pre-treatment pada limbah tanaman jagung terhadap proses anaerobik digesi yang meliputi efisiensi proses digesi dan produksi biogas yang dihasilkan. Penelitian ini dilakukan dengan menggunakan reaktor tipe batch yang suhunya dipertahankan pada kondisi mesophilic atau di atas rata-rata suhu kamar (33 \pm 2 $\left.{ }^{\circ} \mathrm{C}\right)$. Hasil penelitian diperoleh bahwa thermal pre-treatment yang diberikan pada limbah tanaman jagung mampu mempercepat proses produksi biogas pada 10 hari pertama sehingga dapat mengurangi lag-phase pada proses anaerobik digesi. Limbah tanaman jagung yang diberikan thermal pre-treatment mengalami perlambatan produksi biogas pada hari ke 26 dengan rata-rata total produksi $12.412,5 \mathrm{~mL}$ untuk limbah tanaman jagung yang diberikan thermal pretreatment selama 15 menit, dan $12.310 \mathrm{~mL}$ untuk limbah tanaman jagung yang diberikan thermal pre-treatment selama 25 menit, sedangkan limbah tanaman jagung yang tidak diberikan pre-treatment menghasilkan produksi biogas sebesar $12.557 \mathrm{~mL}$ pada hari ke 26. Produksi biogas harian tertinggi terjadi pada substrat yang diberikan thermal pre-treatment 25 menit, dengan produksi biogas tertinggi pada hari ke 9 dengan rata-rata produksi sebesar $915 \mathrm{~mL}$. Substrat yang diberikan thermal pre-treatment 15 menit juga memproduksi biogas jauh lebih tinggi $(772,5 \mathrm{~mL})$ pada hari ke 9 jika dibandingkan dengan substrat tanpa diberikan pre-treatment yang hanya memproduksi biogas sebesar $405 \mathrm{~mL}$. Data hasil penelitian menunjukkan bahwa limbah tanaman jagung yang diberikan thermal pre-treatment memperoleh biogas yield lebih tinggi dari pada yang tidak diberikan pre-treatment dimana $670,39 \mathrm{~mL} / \mathrm{g}$ volatile solids untuk thermal pretreatment 15 menit, $690,65 \mathrm{~mL} / \mathrm{g}$ volatile solids untuk thermal pre-treatment 25 menit dan $456,37 \mathrm{~mL} / \mathrm{g}$ volatile solids untuk limbah tanaman jagung yang tidak diberikan pre-treatment.
\end{abstract}

Kata kunci: Thermal pre-treatment, limbah tanaman jagung, anaerobik digesi, biogas

\begin{abstract}
Thermal pre-treatment was given on corn stover in the purpose of breaking the lignin content; thus, it may help anaerobic microorganisms to convert polymer including cellulose and hemicelluloses into biogas. This study aimed to investigate the effects of thermal pre-treatment on corn stover in anaerobic digestion process related to the production of biogas as well as digestion process efficiency. This research was carried out by utilizing batch reactors where the temperature was maintained at mesophilic conditions above room temperature $\left(33 \pm 2{ }^{\circ} \mathrm{C}\right)$. Based on the result, it was known that thermal pre-treatment given on the corn stover may enhance anaerobic digestion process for biogas production at the first 10 days. This condition reduced the time of lag phase during anaerobic digestion. The biogas production of corn stover given thermal pre-treatment was slow at 26 days where their average total production were 12,412.5 mL, $12,310 \mathrm{~mL}$ at 15 and 25 minutes thermal pre-treatment, respectively while biogas production of non pre-treated corn stover was $12,557 \mathrm{~mL}$. The highest daily biogas production was accomplished by corn stover that was given thermal
\end{abstract}


pre-treatment at 25 minutes $(915 \mathrm{~mL})$. Corn stover given with 15 minutes thermal pre-treatment also generated higher daily biogas production at day $9(772.5 \mathrm{~mL})$ compared with corn stover that was not pre-treated $(405 \mathrm{~mL})$. This research also revealed that corn stover given thermal pre-treatment reached higher biogas yield compared with non pre-treated corn stover where their biogas yield were $670.39,690.65 \mathrm{~mL} / \mathrm{g}$ volatile solids added at 15 and 25 minutes thermal pretreatment respectively, and $456.37 \mathrm{~mL} / \mathrm{g}$ volatile solids added of non pre-treated corn stover.

Keywords: Thermal pre-treatment, corn stover, anaerobic digestion, biogas

\section{PENDAHULUAN}

Secara umum limbah tanaman jagung yaitu limbah hasil panen tanaman jagung yang ditinggalkan setelah bonggol atau buah jagungnya dipetik yang terdiri dari batang, daun, tongkol dan kulit jagung (Regional Agronomist, 2007). Limbah tanaman jagung (corn stover) juga merupakan biomassa lignoselulosa yang terdiri dari beberapa komponen penyusunnya yaitu lignin, selulosa, dan hemiselulosa. Cheng dkk. (2010) mengungkapkan bahwa sebagai biomassa lignoselulosa, limbah tanaman jagung terdiri dari 7-8\% lignin, $35-40 \%$ selulosa, dan $17-35 \%$ hemiselulosa. Sebagai biomassa lignoselulosa, limbah tanaman jagung memiliki potensi untuk digunakan sebagai bahan baku (feedstock) pada proses produksi bioenergi. Walaupun produksi energi alternatif dapat juga diperoleh dari biomassa dan produk hasil pertanian lainnya, akan tetapi produksi energi dengan menggunakan bahan baku limbah tanaman jagung lebih menguntungkan karena bahan bakunya tersedia dalam jumlah yang besar tanpa harus berkompetisi dengan kebutuhan bahan pangan seperti memproduksi energi alternatif dengan menggunakan singkong, jarak pagar yang membutuhkan waktu tanam, biaya produksi serta lahan tanam (US DOE, 2001).

Waish dkk. (1988) menyatakan bahwa biogas yang diproduksi dari anaerobik reaktor menghasilkan kandungan metan yang tinggi dibandingkan dengan biogas yang dihasilkan dari tumpukan sampah dan limbah yang ada di lapangan. Selama proses anaerobik digesi, ada beberapa jenis gas yang dihasilkan. Komposisi biogas yang dihasilkan dari proses anaerobik digesi terdiri dari $60 \%$ sampai $70 \%$ metan, 30\% sampai dengan $40 \%$ karbondioksida, serta gasgas lainnya seperti hidrogen sulfida dan ammonia (Hansen, 2003).

Proses anaerobik digesi dengan menggunakan limbah tanaman jagung sebagai co-substrat dapat terhambat dengan adanya kandungan lignin. Seperti yang telah diketahui bahwa kandungan lignin yang terdapat pada limbah jagung tidak dapat terurai selama proses anaerobik digesi (Hendriks dan Zeeman, 2009; Wang dan Schmidt, 2010). Hal ini terjadi selama proses hidrolisis dimana mikroorganisme serta enzim ekstra seluler terhalang oleh komponen lignin sehingga tidak mampu mengakses nutrisi yang terdiri dari selulosa dan hemiselulosa untuk dikonversikan menjadi gula (Rubia dkk., 2011).

Anaerobik co-digesi dapat meningkatkan proses digesi dari beberapa limbah yang mengandung karbohidrat, protein dan lemak yang mungkin tidak dapat terurai dengan mudah (Darwin dkk., 2014; Mondragón dkk., 2006). Beberapa penelitian terdahulu telah mengungkapkan bahwa anaerobik digesi yang dilakukan dengan beberapa jenis co-substrat seperti limbah batang jagung, limbah tanaman gandum, jerami padi, switchgrass mampu meningkatkan produksi biogas dan metan dengan jumlah yang sangat signifikan (Crolla dkk., 2011; Darwin dkk., 2014; Gontupil dkk., 2012). Penambahan 30\% co-substrat mampu meningkatkan methane yield yang merupakan jumlah total gas metan yang dihasilkan dibagi dengan jumlah kandungan volatile solids bahan yang digunakan, dimana methane yield yang dihasilkan sekitar 1,2 sampai 1,6 kali lipat dibandingkan dengan anaerobik digesi yang hanya menggunakan limbah manure sapi (Crolla dkk., 2011; Lo dkk., 1984).

Biogas merupakan suatu produk yang diperoleh dari hasil proses penguraian bahan-bahan organik yang dilakukan oleh mikroorganisme (Waish dkk., 1988). Osho (2010) menyebutkan bahwa fermentasi dari limbah biologi serta manure yang diperoleh dari proses peternakan yang terdiri dari urine dan feses pada tempat tertutup tanpa adanya udara dan menghasilkan gas sebagai hasil dari aktivitas mikroorganisme disebut dengan biogas. Hal ini berarti bahwa biogas merupakan produk akhir dari fermentasi mikrobiologi atau produk dari proses metabolisme yang dilakukan oleh bakteri methanogenic (Nagy and Szabó, 2011).

Rubia dkk. (2011) menyatakan bahwa bakteri hydrolitic menguraikan substrat sangat lambat selama proses anaerobik digesi yang disebabkan oleh adanya struktur kimia dan fisika yang sangat keras dari bahan-bahan biomassa lignoselulosa. Untuk menghindari penyumbatan pada digester serta mengurangi resiko kegagalan pada proses anaerobik digesi karena sulitnya mikroorganisme memecahkan dan menghancurkan substrat dari biomassa lignoselulosa maka perlu dilakukan pengecilan ukuran dari feedstock yang akan digunakan. 
Faktor utama yang mempengaruhi produksi bio-metan pada proses anaerobik digesi biomassa lignoselulosa yaitu sifat-sifat intrinsik dari biomassa itu sendiri, serta aktivitas mikro-organisme yang terdapat di dalam digester. Proses pretreatment terhadap biomassa lignoselulosa sangat penting dilakukan sebelum bahan tersebut dimasukan ke dalam reaktor anaerobik. Proses ini penting dilakukan untuk memecahkan rantai polimer menjadi molekul yang lebih kecil sehingga memudahkan mikro-organisme untuk memperoleh dan mengkonversi selulosa menjadi biogas (Wang dan Schmidt, 2010). Dengan melakukan pre-treatment maka struktur dari biomassa lignoselulosa akan dipecahkan sehingga komponen dari biomassa yang mengandung gula akan mudah diakses oleh mikro-organisme anaerobik (Wang dkk., 2009). Zhang dan Zhiqin (1999) menyebutkan bahwa pengecilan ukuran secara mekanis dapat membantu peningkatan proses biodegradasi oleh mikroorganisme dimana dengan melakukan pengecilan ukuran dinding sel dari biomassa akan dipecahkan sehingga komponen-komponen organik yang mudah terurai akan lebih mudah diakses oleh mikroorganisme.

Thermal pre-treatment merupakan metode yang sangat menjanjikan dan memiliki berbagai keuntungan untuk diterapkan pada proses konversi limbah biomassa lignoselulosa menjadi bioenergi. Hal ini karena thermal pretreatment dapat memecahkan kandungan lignin pada limbah biomassa lignoselulosa tanpa memerlukan tambahan bahanbahan kimia seperti sodium hidroksida, sehingga penerapan metode ini sangat ekonomis untuk diterapkan. Studi yang dilakukan oleh Lei dkk. (2013) mengungkapkan bahwa penerapan hydrothermal pre-treatment pada biomassa jenis herbal dapat mengoptimalkan proses hidrolisis, dimana dengan diberikannya thermal pre-treatment pada limbah biomassa maka akan mempermudahkan proses hidrolisis dalam mengkonversi senyawa komplek seperti selulosa menjadi komponen sederhana seperti gula.

Studi yang dilakukan oleh Alvira dkk. (2010) mengungkapkan bahwa penerapan thermal pre-treatment pada limbah biomassa lignoselulosa untuk dikonversikan menjadi bioenergi sangat dianjurkan karena dianggap sebagai metode pre-treatment limbah biomassa yang aman dan ramah terhadap lingkungan karena tidak meninggalkan residu bahan-bahan kimia yang dapat merusak lingkungan. Thermal pre-treatment dengan menggunakan air panas juga diketahui dapat meningkatkan perubahan struktur fisik dari biomassa lignoselulosa sehingga dapat mengoptimalkan proses hidrolisis untuk menghasilkan gula (Mosier dkk., 2005; Lei dkk., 2013). Perubahan-perubahan struktur fisika dari biomassa lignoselulosa yang diberikan perlakuan thermal pre-treatment dengan menggunakan air panas meliputi pengurangan struktur kristal atau kandungan lignin, peningkatan proses enzimatis pada tahapan hidrolisis, peningkatan ukuran pori-pori biomassa lignoselulosa sehingga memudahkan enzim-enzim hidrolisis dalam mengakses selulosa untuk selanjutnya dikonversikan menjadi gula (Walch dkk., 1992; Mok dkk., 1992; Grethlein, 1985).

Dengan demikian pre-treatment pada limbah tanaman jagung perlu dilakukan untuk melunakkan serta memecahkan lignin sehingga mikroorganisme dapat dengan mudah mengkonversikan selulosa dan hemiselulosa menjadi gula dan untuk selanjutnya dikonversikan menjadi biogas. Oleh karena itu, pada penelitian ini dilakukan thermal pre-treatment pada limbah tanaman jagung dengan berbagai variasi waktu untuk meningkatkan efisiensi pada proses anaerobik digesi dalam memproduksi biogas.

\section{METODE PENELITIAN}

\section{Bahan dan Alat}

Bahan-bahan yang dipergunakan adalah limbah tanaman jagung yang diperoleh dari perkebunan rakyat di Desa Lambeugak, Kecamatan Kuta Cot Gile, Aceh Besar, dan inokulum yang digunakan sebagai starter untuk mempercepat proses anaerobik digesi dalam memproduksi biogas diperoleh dari digester semi kontinu yang dioperasikan pada kondisi steady state dengan suhu dipertahankan pada kondisi mesophilic atau di atas rata-rata suhu kamar $\left(33 \pm 2{ }^{\circ} \mathrm{C}\right)$. Peralatan yang digunakan dalam penelitian ini antara lain: $\mathrm{pH}$ meter, oven untuk mengukur kadar air dan total solids bahan, furnace untuk mengukur volatile solids, hammer mill untuk pengecilan ukuran limbah tanaman jagung kering, water displacement gasmeter untuk mengukur biogas yang dihasilkan, thermostatic waterbath untuk tempat reaktor anaerobik beroperasi, corong (funnel), anaerobik digester berukuran 1,5 liter, gelas ukur plastik untuk persiapan bahan, syringe untuk stimulasi pengeluran bahan hasil digesi serta alat penunjang penelitian lainnya.

\section{Pengisian Bahan (Material Loading) ke dalam Reaktor}

Langkah pengisian bahan ke dalam anaerobik reaktor adalah sebagai berikut: (1) Limbah hasil panen tanaman jagung yang diperoleh berupa tongkol, batang dan daun dikeringkan terlebih dahulu (kadar air 7,31 \pm 3,54 \%), kemudian dilakukan pengecilan ukuran $\pm 2 \mathrm{~mm}$ dengan menggunakan alat penggiling (hammer mill). Limbah jagung yang sudah digiling, kemudian dilakukan analisis total solids dan volatile solids-nya. Analisis ini diperlukan karena pada proses anaerobik digesi kandungan volatile solids dari limbah biomassa juga merepresentasikan kandungan organik yang terkandung dalam bahan tersebut yang dapat dikonversikan menjadi biogas (Schmidt, 2005). (2) Limbah tanaman jagung yang sudah digiling dilakukan thermal pre-treatment yaitu 
dengan cara dimasukkan ke dalam wadah yang berisi air panas dengan temperature $100 \pm 5{ }^{\circ} \mathrm{C}$. Durasi pemanasan disesuaikan dengan perlakuan percobaan yaitu 15 dan 25 menit. (3) Dilakukan pengukuran total solids dan volatile solids dari limbah tanaman jagung yang sudah digiling dan yang sudah dilakukan thermal pre-treatment, serta inokulum atau starter yang digunakan. Inokolum yang digunakan pada penelitian ini yaitu $10 \% \mathrm{v} / \mathrm{v}$ dari 1 liter volume kerja reaktor anaerobik yang digunakan. Inokulum ini diperoleh dari effluent proses anaerobik digesi limbah manure sapi yang dioperasikan pada reaktor semi kontinu yang suhunya juga dipertahankan pada kondisi mesophilic atau di atas ratarata suhu kamar $\left(33 \pm 2{ }^{\circ} \mathrm{C}\right)$. (4) Proses anaerobik dilakukan pada konsentrasi 3\% total solids. Persentase atau jumlah biomassa (limbah tanaman jagung yang diberikan thermal pre-treatment dan yang tidak diberikan pre-treatment) yang dimasukkan ke dalam reaktor didasarkan pada jumlah inokulum (11,3 g/L) dan biomassa $(20,17 \mathrm{~g} / \mathrm{L})$. Inokulum yang digunakan pada penelitian ini memiliki karakteristik berupa $\mathrm{pH} 7,08$, konsentrasi total solids $1,13 \%$ dan volatile solids $56.8 \%$. Adapun limbah tanaman jagung kering yang digunakan yaitu memiliki total solids 92,69 $\pm 3,54 \%$ dan volatile solids $85,28 \% \pm 4,95 \%$.

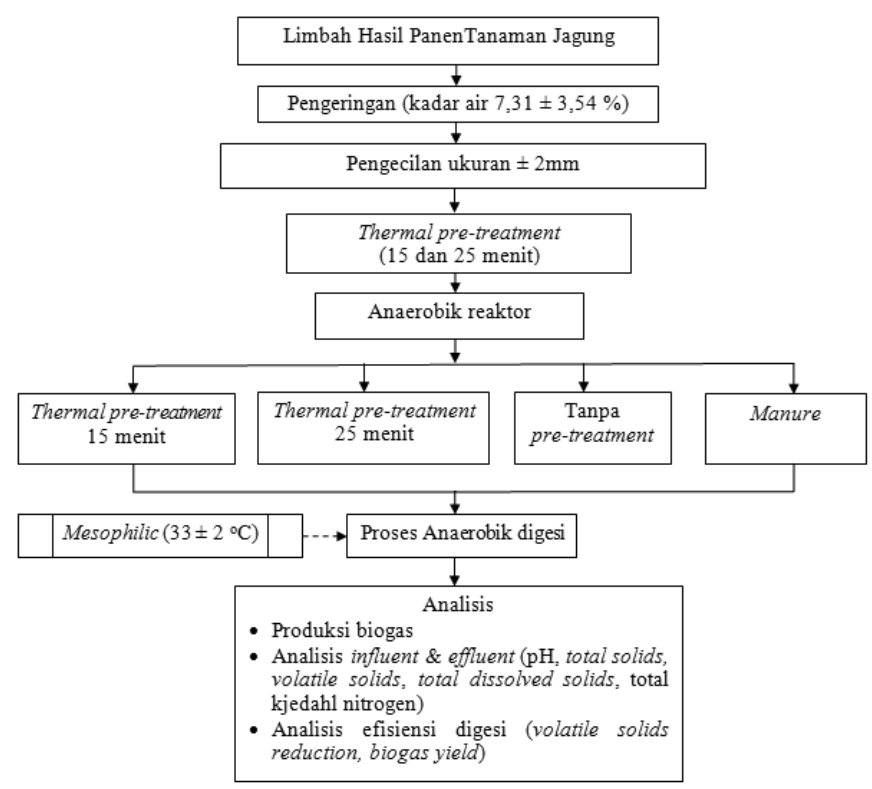

Gambar 1. Diagram alir tahapan penelitian

\section{Proses Anaerobik Digesi}

Reaktor yang sudah diisikan dengan substrat, yang meliputi reaktor yang hanya berisi inokulum dan manure sapi, reaktor yang berisi inokulum dan limbah tanaman jagung yang tidak diberikan pretreatment, serta inokulum dan limbah tanaman jagung yang diberikan thermal pretreatment diletakkan di dalam thermostatic waterbath yang suhunya dipertahankan pada kondisi mesophilic atau di atas ratarata suhu kamar $\left(33 \pm 2{ }^{\circ} \mathrm{C}\right)$. Pengukuran produksi biogas dilakukan setiap hari dengan mencatat peningkatan level gas pada gas meter. Pada proses anaerobik digesi ini, biogas yang dihasilkan dari reaktor dihubungkan ke tabung yang berisi air dan kemudian biogas tersebut dialirkan ke tabung gas meter. Biogas yang dialirkan ke tabung yang berisi air bertujuan untuk membersihkan kandungan biogas dari komponenkomponen yang tidak diinginkan seperti hidrogen sulfida $\left(\mathrm{H}_{2} \mathrm{~S}\right)$ dan karbon dioksida $\left(\mathrm{CO}_{2}\right)$ (Zhao dkk., 2010; Darwin dkk., 2014). Metode ini diterapkan karena $\mathrm{CO}_{2}$ dan $\mathrm{H}_{2} \mathrm{~S}$ merupakan komponen dari biogas yang lebih mudah larut di dalam air dibandingkan gas metan (Zhao dkk., 2010).

\section{Pengamatan dan Analisis}

Parameter anaerobik digesi yang diamati yaitu produksi biogas per hari, pengukuran $\mathrm{pH}$, total solids (TS), volatile solids (VS), total dissolved solids (TDS) dan total kjedahl nitrogen (TKN) terhadap bahan yang dimasukkan (influent) ke dalam reaktor dan bahan yang dikeluarkan (effluent) dari reaktor setelah selesainya proses anaerobik digesi yang ditandai dengan berhentinya produksi biogas. Analisa sampel influent dan effluent ini dilakukan berdasarkan "metode standar" (APHA, 1998).

Durasi proses anaerobik digesi serta pengukuran produksi biogas ditentukan berdasarkan seberapa lama proses anaerobik digesi dari tiap-tiap reaktor menghasilkan biogas. Pengukuran parameter efisiensi digesi diperlukan untuk mengetahui kinerja dari tiap-tiap reaktor anaerobik dalam menjalani proses anaerobik digesi (Joane, 1991; Darwin dkk., 2014), pengukuran parameter efisiensi digesi yang dilakukan pada penelitian ini meliputi volatile solids reduction, dan biogas yield.

\section{HASIL DAN PEMBAHASAN}

\section{Produksi Biogas}

Produksi biogas dari manure, tanpa penambahan feedstock limbah tanaman jagung sangat sedikit dibandingkan dengan produksi biogas dari campuran manure sapi dan limbah tanaman jagung (co-digesi). Hasil penelitian menunjukkan bahwa produksi rata-rata biogas kumulatif dari manure sapi selama 47 hari mengalami peningkatan yang tidak signifikan, dengan total produksi biogas sampai hari ke-47 adalah 887,5 mL. Produksi rata-rata biogas kumulatif dari manure sapi yang dicampurkan dengan limbah tanaman jagung tanpa pre-treatment terus mengalami peningkatan, dimana produksi biogasnya pada hari ke-47 adalah 15.969,5 $\mathrm{mL}$. Limbah tanaman jagung dengan thermal pre-treatment selama 15 menit menghasilkan total produksi biogasnya yaitu 
14.362,5 mL. Produksi rata-rata biogas kumulatif dari manure yang dicampurkan dengan limbah tanaman jagung dengan thermal pre-treatment selama 25 menit adalah $14.225 \mathrm{~mL}$. Dari hasil penelitian dapat diketahui bahwa durasi thermal pre-treatment yang diberikan pada limbah tanaman jagung selama 15 dan 25 menit tidak jauh berbeda untuk biogas yang dihasilkan. Hasil ini dapat terlihat dari produksi biogas dari kedua variasi thermal pre-treatment yang menghasilkan jumlah produksi biogas yang hampir sama, dimana total produksi selama 47 hari proses digesi yaitu $14.225 \mathrm{~mL} \mathrm{(25}$ menit thermal pre-treatment) dan 14.362,5 mL (15 menit thermal pre-treatment).

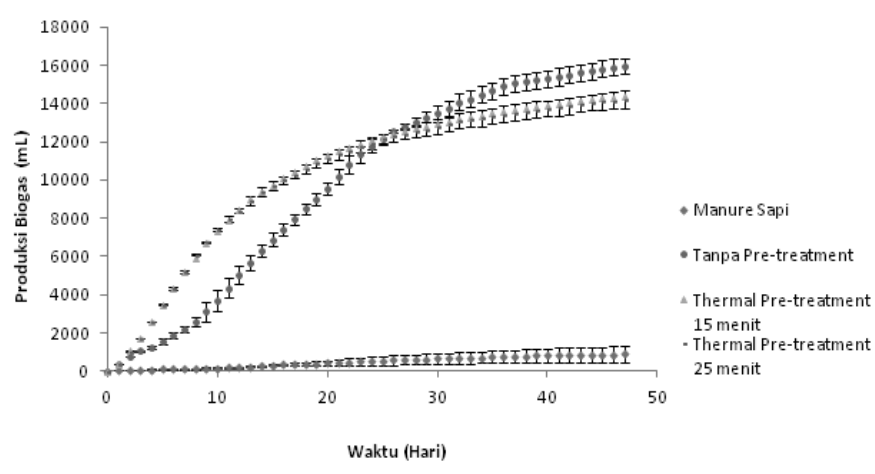

Gambar 2. Produksi biogas dari substrat yang diberikan thermal pre-treatment, tanpa pre-treatment dan manure sapi

Dari keempat jenis substrat yang diberikan pada anaerobik reaktor, total produksi biogas tertinggi selama 47 hari proses digesi diperoleh dari manure dengan campuran limbah tanaman jagung tanpa pre-treatment $(15.969,5 \mathrm{~mL})$. Hal ini dikarenakan jumlah bahan makanan (substrat) yang dibutuhkan oleh mikroorganisme sulit untuk didegradasikan karena memiliki kandungan lignin yang tinggi oleh karena tidak dilakukannya thermal pre-treatment, sehingga jumlah bahan makanan bisa bertahan lebih lama dan secara bertahap substrat tersebut dikonsumsi oleh mikroorganisme untuk meningkatkan produksi biogas. Total produksi biogas dari substrat yang tidak diberikan thermal pre-treatment hanya berkisar $10 \%$ lebih tinggi dari total produksi biogas pada substrat yang diberikan thermal pre-treatment. Akan tetapi, jika dilihat pada Gambar 2 dapat diketahui bahwa substrat yang tidak diberikan pre-treatment memiliki waktu lag phase yang lebih panjang jika dibandingkan dengan substrat yang telah diberikan thermal pre-treatment. Hasil ini juga sesuai dengan penelitian yang dilakukan oleh Bougrier dkk. (2008) yang mengungkapkan bahwa penerapan thermal pre-treatment pada susbtrat yang berupa lumpur aktif untuk proses anaerobik digesi juga dapat meningkatkan produksi biogas. Peningkatan volume produksi biogas ini berkaitan dengan peningkatan jumlah bahan-bahan organik yang mudah terlarut di dalam air sehingga memudahkan proses konversi limbah organik tersebut menjadi biogas. Penerapan thermal pre-treatment pada feedstock yang memiliki tingkat kekerasan yang tinggi juga sangat mempengaruhi peningkatan laju proses penguraian kandungan bahan-bahan organik selama proses anaerobik digesi (Bougrier dkk., 2008)

Berdasarkan Gambar 2, substrat dari manure yang dicampur limbah tanaman jagung dengan thermal pretreatment (15 dan 25 menit) mengalami peningkatan jumlah produksi biogas yang signifikan bila dibandingkan substrat yang tidak dilakukan thermal pre-treatment. Hal ini dapat terlihat jelas bahwa selama proses anaerobik digesi dari hari pertama sampai hari ke 20, produksi biogas yang dihasilkan dari substrat yang diberikan thermal pre-treatment lebih tinggi 15,29\% jika dibandingkan dengan substrat yang tidak diberikan thermal pre-treatment. Hasil ini masih sedikit lebih rendah jika dibandingkan dengan beberapa hasil penelitian yang telah dilakukan oleh Gavala dkk. (2003) dan Bougrier dkk. (2008) yang mengungkapkan adanya peningkatan produksi biogas sekitar 20-30\% pada substrat lumpur aktif yang diberikan thermal treatment pada suhu $70-121^{\circ} \mathrm{C}$.

Peningkatan produksi biogas terjadi karena tingginya laju proses hidrolisis yang terjadi pada substrat yang diberikan thermal pre-treatment dibandingkan dengan substrat yang tanpa diberikan pre-treatment, sehingga di awal proses anaerobik digesi dari substrat yang diberikan thermal pre-treatment dapat menghasilkan biogas yang lebih tinggi. Hal ini sesuai dengan studi yang dilakukan oleh Wang dkk. (2009) yang menyatakan bahwa dengan memberikan pretreatment pada limbah biomassa lignoselullosa maka struktur dari biomassa lignoselulosa akan mudah dipecahkan sehingga komponen dari biomassa yang mengandung selulosa akan mudah diakses oleh mikro-organisme anaerobik (Wang dkk., 2009; Mosier dkk., 2005; Lei dkk., 2013). Dari hasil penelitian juga dapat diketahui bahwa produksi biogas harian tertinggi terjadi pada substrat yang diberikan thermal pretreatment 25 menit, dengan produksi biogas tertinggi pada hari ke 9 dengan rata-rata produksi sebesar $915 \mathrm{~mL}$. Pada hari ke-9, substrat yang diberikan pre-treatment 15 menit juga memproduksi biogas jauh lebih tinggi $(772,5 \mathrm{~mL})$ jika dibandingkan dengan substrat tanpa diberikan pre-treatment yang hanya memproduksi biogas sebesar $405 \mathrm{~mL}$.

Penerapan thermal pre-treatment yang diberikan pada limbah tanaman jagung juga dapat mempermudah mikroorganisme anaerobik untuk menguraikan kandungan bahan organik selama proses anaerobik digesi. Hal ini terjadi karena lignin yang terkandung di dalam limbah tanaman jagung telah berkurang akibat dari proses thermal pretreatment, sehingga substrat yang tersedia seperti selulosa dapat lebih cepat dimanfaatkan oleh mikroorganisme 
untuk menghasilkan biogas. Setelah beberapa hari proses anaerobik digesi, nutrisi di dalam reaktor berkurang sehingga mikroorganisme mengalami kekurangan makanannya dan mengakibatkan produksi biogas juga ikut menurun.

Meskipun limbah tanaman jagung yang telah diberikan thermal pre-treatment menghasilkan total produksi biogas lebih sedikit jika dibandingkan dengan yang tidak diberikan pre-treatment. Akan tetapi proses anaerobik digesi yang diberikan thermal pre-treatment tidak memerlukan waktu yang lama, hal ini terjadi karena terjadinya peningkatan laju proses hidrolisis pada limbah tanaman jagung yang telah diberikan thermal pre-treatment sehingga produksi biogas dapat ditingkatkan dalam waktu yang cepat. Dengan pemberian thermal pre-treatment pada limbah tanaman jagung juga dapat meningkatkan efisiensi proses anaerobik digesi sehingga bakteri dapat dengan cepat mengkonversikan selulosa menjadi biogas. Hasil ini sesuai dengan penelitian yang telah dilakukan oleh Lei dkk. (2013) yang mengungkapkan bahwa penerapan thermal pre-treatment dengan menggunakan air panas pada biomassa lignoselulosa akan meningkatkan laju proses hidrolisis untuk mengkonversi selulosa menjadi komponen sederhana yang berupa gula, dan selanjutnya produk hasil hidrolisis ini akan dikonversikan menjadi produk fermentasi seperti alkohol dan volatile fatty acids, yang kemudian akan dikonversikan menjadi gas metan pada tahap proses methanogenesis.

\section{Parameter Anaerobik Digesi}

Tabel 1 dan Tabel 2 menunjukkan bahwa secara keseluruhan proses anaerobik digesi yang dilakukan berjalan dengan stabil, hal ini dapat diketahui dari nilai $\mathrm{pH}$ dari kedua proses digesi yang mendekati pada rentang $\mathrm{pH}$ optimum untuk produksi biogas melalui proses anaerobik digesi. Berdasarkan literatur, $\mathrm{pH}$ optimum untuk produksi biogas terjadi pada rentang pH 6,4 dan 7,2 (Dinamarca dkk., 2003; Cheng, 2010). Dari Tabel 1, dapat dilihat bahwa pH influent dari anaerobik co-digesi limbah tanaman jagung dan manure sapi cukup rendah yaitu 5,83. Rendahnya $\mathrm{pH}$ karena pada saat ditambahkan limbah organik ke dalam reaktor anaerobik maka kecenderungan yang akan terjadi yaitu adanya peningkatan tingkat keasaman pada campuran limbah organik di dalam digester. Peningkatan keasaman ini juga disebabkan adanya peningkatan produksi volatile fatty acids pada culture atau campuran di dalam reaktor, dimana setelah mengalami proses hidrolisis dilanjutkan pada proses acidifikasi yang mengkonversi produk hasil dari tahapan hidrolisis yang berupa senyawa sederhana seperti gula menjadi beberapa komponen volatile fatty acids seperti asam propionat, asam butirat dan asam asetat (Cheng, 2010). Pada tahapan proses acidifikasi ini juga menghasilkan produk alkohol seperti etanol (Han dkk., 2011). Setelah melalui proses acidifikasi, volatile fatty acids tersebut terurai menjadi asam asetat, hidrogen dan karbondioksida, yang selanjutnya pada tahap akhir proses anaerobik digesi yaitu tahapan methanogenesis dimana asam asetat dari hasil proses acetogenesis dikonversikan menjadi biogas yang terdiri dari gas metan, dan karbon dioksida. Hal ini juga dapat dilihat pada Tabel 2, dimana $\mathrm{pH}$ effluent dari anaerobik co-digesi limbah tanaman jagung dan manure sapi meningkat menjadi 6,76 dimana $\mathrm{pH}$ ini termasuk pada $\mathrm{pH}$ optimum untuk produksi biogas.

Tabel 1. Analisis sampel parameter influent sebelum proses anaerobik digesi

\begin{tabular}{|c|c|c|c|c|c|c|}
\hline \multirow[b]{2}{*}{ No } & \multirow[b]{2}{*}{ Substrat } & \multicolumn{5}{|c|}{ Parameter } \\
\hline & & $\mathrm{pH}$ & $\begin{array}{c}\text { TDS } \\
(\mathrm{mg} / \mathrm{L})\end{array}$ & TS (\%) & VS (\%) & $\begin{array}{r}\mathrm{TKN} \\
(\mathrm{mg} / \mathrm{L})\end{array}$ \\
\hline 1 & Manure sapi & 6,55 & 1050 & $1,13 \pm 0,12$ & $56,79 \pm 0,79$ & 155,06 \\
\hline 2 & $\begin{array}{l}\text { Manure sapi dan limbah tanaman } \\
\text { jagung tanpa pre treatment }\end{array}$ & 5,83 & 1680 & $4,44 \pm 0,18$ & $78,79 \pm 3,06$ & 462,16 \\
\hline 3 & $\begin{array}{l}\text { Manure sapi dan limbah tanaman } \\
\text { jagung dengan thermal pre treatment } \\
15 \text { menit }\end{array}$ & 6,72 & 1380 & $2,81 \pm 0,08$ & $76,16 \pm 0,33$ & 386,87 \\
\hline 4 & $\begin{array}{l}\text { Manure sapi dan limbah tanaman } \\
\text { jagung dengan thermal pre treatment } \\
25 \text { menit }\end{array}$ & 6,5 & 1400 & $2,73 \pm 0,13$ & $75,42 \pm 0,53$ & 474,24 \\
\hline
\end{tabular}


Tabel 2. Analisis sampel parameter effluent sesudah mengalami proses anaerobik digesi

\begin{tabular}{|c|c|c|c|c|c|c|}
\hline \multirow[b]{2}{*}{ No } & \multirow[b]{2}{*}{ Substrat } & \multicolumn{5}{|c|}{ Parameter } \\
\hline & & $\mathrm{pH}$ & $\begin{array}{c}\text { TDS } \\
(\mathrm{mg} / \mathrm{L})\end{array}$ & TS (\%) & VS (\%) & TKN (mg/L) \\
\hline 1 & Manure sapi & $6,95 \pm 0.02$ & $1740 \pm 14$ & $0,976 \pm 0,02$ & $30,879 \pm 12,09$ & $231 \pm 40,53$ \\
\hline 2 & $\begin{array}{l}\text { Manure sapi dan limbah } \\
\text { tanaman jagung tanpa pre } \\
\text { treatment }\end{array}$ & $6,76 \pm 0,04$ & $2240 \pm 28$ & $1,3485 \pm 0,08$ & $60,48 \pm 4,41$ & $412,54 \pm 11,58$ \\
\hline 3 & $\begin{array}{l}\text { Manure sapi dan limbah } \\
\text { tanaman jagung dengan thermal } \\
\text { pre treatment } 15 \text { menit }\end{array}$ & $6,73 \pm 0$ & $1975 \pm 35$ & $1,118 \pm 0,07$ & $57,3315 \pm 4,27$ & $447,24 \pm 141,17$ \\
\hline 4 & $\begin{array}{l}\text { Manure sapi dan limbah } \\
\text { tanaman jagung dengan thermal } \\
\text { pre treatment } 25 \text { menit }\end{array}$ & $6,85 \pm 0,03$ & $2020 \pm 28$ & $1,312 \pm 0,26$ & $63,237 \pm 6,54$ & $484,48 \pm 98,99$ \\
\hline
\end{tabular}

Meskipun anaerobik digesi manure sapi memiliki $\mathrm{pH}$ yang mendekati optimum untuk produksi biogas, akan tetapi anaerobik digesi yang hanya menggunakan manure sapi sebagai substrat tunggal tidak memiliki cukup nutrisi yang dibutuhkan oleh bakteri anaerobik untuk menghasilkan biogas. Hal ini dapat terlihat dari rendahnya kandungan total solids (TS) dan volatile solids (VS) dari manure sapi yaitu sebesar 1,13 $\pm 0,12 \%$ TS dan 56,79 $\pm 0,79 \%$ VS. Sedangkan anaerobik digesi manure sapi yang ditambahkan limbah tanaman jagung sebagai co-substrate memiliki kandungan total solids dan volatile solids lebih tinggi dari anaerobik digesi dengan hanya menggunakan manure sapi. Nilai total solids dan volatile solids dari anaerobik digesi manure sapi yang ditambahkan limbah tanaman jagung yaitu sebesar $4,44 \pm 0,18 \%$ TS dan 78,79 $\pm 3,06 \%$ VS. Untuk substrat campuran dari manure sapi dan limbah tanaman jagung yang telah diberikan thermal pre-treatment 15 menit, memiliki kandungan total solids dan volatile solids sebesar 2,81 $\pm 0,08$ \%TS dan 76,16 $\pm 0,33 \%$ VS. Pada substrat campuran dari manure sapi dan limbah tanaman jagung yang telah diberikan thermal pre-treatment 25 menit, memiliki kandungan total solids dan volatile solids sebesar $2,73 \pm 0,13 \% \mathrm{TS}$ dan 75,42 $\pm 0,53 \%$ VS.

Parameter Total Dissolved Solids (TDS) pada keempat proses anaerobik digesi juga terjadi peningkatan dari sebelum mengalami proses anaerobik digesi (influent) dan setelah mengalami proses anaerobik digesi (effluent). Peningkatan kandungan TDS terjadi karena pada proses anaerobik digesi mengalami proses penguraian senyawa organik kompleks menjadi molekul-molekul sederhana yang larut dalam air yang selanjutnya digunakan untuk proses produksi biogas (Jayakody dkk., 2007). TDS dari anaerobik codigesi limbah tanaman jagung dan manure sapi juga lebih tinggi dibandingkan dengan anaerobik digesi yang hanya menggunakan manure sapi sebagai substrat tunggal (Tabel 1 dan Tabel 2).

Untuk Total Kjedahl Nitrogen (TKN) pada anaerobik digesi manure sapi juga mengalami peningkatan dari 155,06 $\mathrm{mg} / \mathrm{L}$ menjadi 231,03 mg/L. Peningkatan TKN terjadi karena anaerobik digesi yang hanya menggunakan manure sapi memiliki kapasitas buffer yang rendah, sehingga akumulasi ammonia dapat terjadi di dalam reaktor anaerobik yang pada akhirnya dapat menghambat proses anaerobik digesi untuk menghasilkan biogas. Pada anaerobik co-digesi limbah tanaman jagung dan manure sapi, dimana kandungan TKN terjadi sedikit penurunan dari 462,16 $\mathrm{mg} / \mathrm{L}$ menjadi 412,53 $\mathrm{mg} / \mathrm{L}$. Penurunan TKN pada proses anaerobik digesi dengan menggunakan limbah tanaman jagung sebagai co-substrat terjadi karena adanya peningkatan kapasitas buffer selama proses sehingga dapat meningkatkan kestabilan proses anaerobik digesi untuk mengurangi resiko kegagalan akibat akumulasi ammonia di dalam reaktor anaerobik sehingga pada akhirnya dapat meningkatkan produksi biogas (Banks dan Humphreys, 1998). Perbedaan terjadi juga pada substrat yang diberikan thermal pre-treatment dimana TKN dari kedua substrat yang telah diberikan thermal pre-treatment mengalami sedikit peningkatan setelah mengalami proses anaerobik digesi. Adanya peningkatan kandungan TKN karena proses penguraian substrat sangat cepat terjadi diawal-awal proses anaerobik digesi yang ditandai dengan peningkatan produksi biogas (Gambar 2), yang kemudian diikuti dengan penurunan produksi biogas per harinya setelah lebih dari 10 hari proses digesi. Penurunan produksi biogas terjadi karena adanya pengurangan jumlah nutrisi yang tersedia akibat tingginya laju penguraian nutrisi di awal-awal proses anaerobik digesi. Peningkatan TKN pada substrat 
yang diberikan thermal pre-treatment juga diikuti dengan meningkatnya nilai $\mathrm{pH}$ dari kedua substrat yang diberikan thermal pre-treatment.

Dari penelitian ini juga dapat diketahui bahwa proses anaerobik co-digesi limbah tanaman jagung dan manure sapi mampu memberikan keunggulan dalam memproduksi biogas karena dapat menyediakan nutrisi yang cukup untuk pertumbuhan mikroorganisme methanogen dalam menghasilkan biogas. Anaerobik digesi manure sapi dengan menambahkan limbah tanaman jagung juga dapat memberikan peningkatan kapasitas buffer selama proses anaerobik digesi di dalam reaktor sehingga proses anaerobik yang terjadi menjadi lebih stabil (Banks dan Humphreys, 1998).

\section{Efisiensi Biodegradasi pada Proses Anaerobik Digesi}

Produksi biogas dari proses anaerobik digesi dipengaruhi oleh beberapa faktor diantaranya yaitu biodegradasi dan ketersediaan senyawa-senyawa yang terkandung di dalam biomassa serta kandungan lignin (Kalra dan Panwar, 1986). Biogas dan methane yield yang diperoleh dari jumlah total biogas yang diperoleh per tiap gram volatile solids yang ditambahkan merupakan parameter digesi untuk mengetahui efisiensi proses biodegradasi dari proses konversi limbah organik menjadi biogas (Lo dkk., 1984).

Tabel 3. Efisiensi biodegradasi

\begin{tabular}{lcc}
\hline \multicolumn{1}{c}{ Substrat } & $\begin{array}{c}\text { VS reduction } \\
(\%)\end{array}$ & $\begin{array}{c}\text { Biogas yield } \\
(\mathrm{mL} / \mathrm{g} \mathrm{VS})\end{array}$ \\
\hline $\begin{array}{l}\text { Manure } \\
\text { Manure + limbah tanaman } \\
\text { jagung }\end{array}$ & 66,015 & 137,923 \\
\hline $\begin{array}{l}\text { Manure + limbah tanaman } \\
\text { jagung dengan thermal pre } \\
\text { treatment } 15 \text { menit }\end{array}$ & 57,942 & 656,37 \\
\hline $\begin{array}{l}\text { Manure + limbah tanaman } \\
\text { jagung dengan thermal pre } \\
\text { treatment 25 menit }\end{array}$ & 43,932 & 690,39 \\
\hline
\end{tabular}

Efisiensi proses digesi juga dapat diketahui dengan melihat persentase pengurangan kandungan volatile solids (volatile solids reduction). Persentase pengurangan kandungan volatile solids dari proses anaerobik co-digesi limbah jagung dan manure sapi yaitu sebesar 58,812\%, sedangkan persentase pengurangan volatile solids dari anaerobik digesi manure sapi yaitu sebesar 66,01\%. Pada substrat yang diberikan thermal pre-treatment 15 menit memiliki persentase pengurangan kandungan volatile solids sebesar 57,94\%, dan untuk substrat yang diberikan thermal pre-treatment 25 menit, persentase pengurangan kandungan volatile solidsnya yaitu hanya $43,93 \%$.

Meskipun proses anaerobik digesi limbah tanaman jagung tanpa pre-treatment memiliki persentase pengurangan volatile solids yang sedikit lebih tinggi jika dibandingkan dengan limbah tanaman jagung yang diberikan thermal pre-treatment, akan tetapi biogas yield yang dihasilkan dari anaerobik digesi limbah tanaman jagung yang diberikan thermal pre-treatment jauh lebih tinggi daripada biogas yield yang diperoleh dari limbah tanaman jagung tanpa pre-treatment. Hal ini dapat terjadi karena jumlah volatile solids yang diuraikan oleh bakteria tidak semuanya dapat dikonversikan menjadi biogas karena dalam proses anaerobik digesi perubahan jalur metabolisme dalam menghasilkan produk akhir dapat berbeda, seperti adanya pembentukan beberapa jenis produk yang berbeda dari volatile fatty acids (asam asetat, propionat dan butirat), serta beberapa jenis alkohol seperti etanol dan butanol (Pakarinen dkk., 2008; Zhang dkk., 2005). Biogas yield yang dihasilkan dari masing-masing substrat yaitu $670,39 \mathrm{~mL} / \mathrm{g}$ volatile solids untuk thermal pre-treatment 15 menit, $690,65 \mathrm{~mL} / \mathrm{g}$ volatile solids untuk thermal pre-treatment 25 menit dan 456,37 $\mathrm{mL} / \mathrm{g}$ volatile solids untuk limbah tanaman jagung yang tidak diberikan pre-treatment. Dari hasil penelitian diketahui bahwa walaupun adanya kecenderungan perlambatan produksi biogas dari akhir proses anaerobik digesi limbah tanaman jagung yang diberikan thermal pre-treatment, tetapi produksi hariannya masih tinggi sehingga total produksi biogas dari limbah yang tidak diberikan pre-treatment hanya selisih $10 \%$ lebih tinggi selama 47 hari proses anaerobik digesi.

\section{KESIMPULAN}

Thermal pre-treatment yang diberikan pada limbah tanaman jagung mampu mempercepat proses produksi biogas pada 10 hari pertama sehingga dapat mengurangi lag-phase pada proses anaerobik digesi. Limbah tanaman jagung yang diberikan thermal pre-treatment mengalami perlambatan produksi biogas pada hari ke-26 dengan rata-rata total produksi $12.412,5 \mathrm{~mL}$ pada 15 menit thermal pre-treatment dan $12.310 \mathrm{~mL}$ pada 25 menit thermal pre-treatment, sedangkan limbah tanaman jagung yang tidak diberikan pretreatment menghasilkan produksi biogas sebesar $12.557 \mathrm{~mL}$ pada hari ke-26.

Produksi biogas harian tertinggi terjadi pada substrat yang diberikan thermal pre-treatment 25 menit, dengan produksi biogas tertinggi pada hari ke-9 dengan rata-rata produksi sebesar $915 \mathrm{~mL}$. Substrat yang diberikan thermal pre-treatment 15 menit juga memproduksi biogas jauh lebih tinggi $(772,5 \mathrm{~mL})$ pada hari ke-9 jika dibandingkan 
dengan substrat tanpa diberikan pre-treatment yang hanya memproduksi biogas sebesar $405 \mathrm{~mL}$. Limbah tanaman jagung yang diberikan thermal pre-treatment memperoleh biogas yield yang lebih tinggi dari pada yang tidak diberikan pre-treatment dimana $670,39 \mathrm{~mL} / \mathrm{g}$ volatile solids untuk thermal pre-treatment 15 menit, $690,65 \mathrm{~mL} / \mathrm{g}$ volatile solids untuk thermal pre-treatment 25 menit dan $456,37 \mathrm{~mL} / \mathrm{g}$ volatile solids untuk limbah tanaman jagung yang tidak diberikan pre-treatment.

\section{SARAN}

Beberapa analisis tambahan perlu dilakukan pada penelitian lanjutan seperti analisis komposisi volatile fatty acid, kandungan lignin setelah pemberian thermal pretreatment dan analisis kapasitas buffer dari tiap-tiap culture yang ada di dalam anaerobik reaktor.

\section{UCAPAN TERIMA KASIH}

Terima kasih disampaikan kepada Direktorat Jenderal Pendidikan Tinggi dan Lembaga Penelitian Universitas Syiah Kuala melalui pendanaan penelitian. Penulis juga mengucapkan terima kasih kepada Susi Chairani yang telah memberikan saran dan bantuan administrasi dalam pelaksanaan penelitian.

\section{DAFTAR PUSTAKA}

Alvira, P., Tomás-Pejó, E., Ballesteros, M. dan Negro, M.J. (2010). Pretreatment technologies for an efficient bioethanol production process based on enzymatic hydrolysis: a review. Bioresource Technology 101(13): 4851-4861.

APHA(1998). Standard Methods for the Examination of Water and Wastewater. American Public Health Association (APHA), American Water Works Association, Water Environment Federation, Washington, D.C. USA.

Banks, C.J. dan Humphreys, P.N. (1998). The anaerobic treatment of a ligno-cellulosic substrate offering little natural $\mathrm{pH}$ buffering capacity. Water Science and Technology 38(4-5): 29-35.

Bougrier, C., Delgenes, J.P. dan Carrère, H. (2008). Effects of thermal treatments on five different waste activated sludge samples solubilisation, physical properties and anaerobic digestion. Chemical Engineering Journal 139(2): 236-244.

Cheng, J., Wang, Z. dan Keshwani, D.R. (2010). Biomass to Renewable Energy. CRC Press, Taylor and Francis Group. USA.
Crolla, A., Kinsley, C. Sauve, T. dan Kenedy, K. (2011). Anaerobic digestion of manure with various cosubstrates. Ontario Rural Waste Water Centre 4: 1-3.

Darwin, Cheng, J.J., Liu, Z.M., Gontupil, J. dan Kwon, O.S. (2014). Anaerobic co-digestion of rice straw and digested swine manure with different total solid concentration for methane production. International Journal of Agricultural and Biological Engineering 7(6): 79-90.

Dinamarca, S., Aroca, G., Chamy, R., dan Guerrero L. (2003). The influence of $\mathrm{pH}$ in the hydrolytic stage of anaerobic digestion of the organic fraction of urban solid waste. Water Science Technology 48(6): 249-254.

Gavala, H.N., Yenal, U., Skiadas, I. V., Westermann, P. dan Ahring, B.K. (2003). Mesophilic and thermophilic anaerobic digestion of primary and secondary sludge. Effect of pre-treatment at elevated temperature. Water Research 37(19): 4561-4572.

Gontupil, J., Darwin, M., Liu, Z., Cheng J.J. dan Chen, H. (2012). Anaerobic co-digestion of swine manure and corn stover for biogas production. American Society of Agricultural and Biological Engineers Annual International Meeting, Dallas, Texas, USA. Hal. 13421347.

Grethlein, H.E. (1985). The effect of pore size distribution on the rate of enzymatic hydrolysis of cellulosic substrates. Nature Biotechnology 3(2): 155-160.

Han, W., Wang, Z., Chen, H., Yao, X. dan Li, Y. (2011). Simultaneous biohydrogen and bioethanol production from anaerobic fermentation with immobilized sludge. Journal of Biomedicine and Biotechnology 2011: $1-5$.

Hansen, R.W. (2003). Methane Generation from Livestock Wastes, Equipment 5: (2). Colorado State University. Fort Collins, Colorado.

Hendriks, A.T.W.M. dan Zeeman, G. (2009). Pretreatments to enhance the digestibility of lignocellulosic biomass. Bioresource Technology 100: 10-18.

Jayakody, K.P.K., Menikpura, S.N.M., Basnayake, B.F.A. dan Weerasekara, R. (2007). Development and evaluation of hydrolytic/acidogenic first stage anaerobic reactor for treating municipal solid waste in developing countries. Proceedings of International Conference on Sustainable Solid Waste Management, Chennai, India. Hal. 363-369.

Joanne, K.P. (1991). Applied Math for Wastewater Plant Operators. CRC Press. New York, USA. 
Kalra, M.S. dan Panwar, J.S. (1986).Anaerobic digestion of rice crop residues. Agricultural Wastes 17: 263-269.

Lei, H., Cybulska, I. dan Julson, J. (2013). Hydrothermal pretreatment of lignocellulosic biomass and kinetics. Journal of Sustainable Bioenergy Systems 3(4): 250-259.

Lo, K.V., Liao, P.H., Bulley, N.R. dan Chieng, S.T. (1984). A comparison of biogas production from dairy manure filtrate using conventional and fixed film reactors. CanadianAgricultural Engineering 26(1): 73-78.

Mosier, N., Hendrickson, R., Ho, N., Sedlak, M. dan Ladisch, M.R. (2005). Optimization of $\mathrm{pH}$ controlled liquid hot water pretreatment of corn stover. Bioresource technology 96(18): 1986-1993.

Mok, W.S.L. dan Antal Jr, M.J. (1992). Uncatalyzed solvolysis of whole biomass hemicellulose by hot compressed liquid water. Industrial \& Engineering Chemistry Research 31(4): 1157-1161.

Mondragón, F.A., Samar, P., Cox, H.H., Ahring, B.K. dan Iranpour, R. (2006). Anaerobic codigestion of municipal, farm, and industrial organic wastes: A survey of recent literature. Water Environment Research 78(6): 607-636.

Nagy, V. dan Szabó, E. (2011). Biogas from organic wastes. Studia Universitatis "Vasile Goldis" Seria Stiintele Vietii 21(4): 887-891.

Osho, A. (2010). Green Solution to Blackouts: Investigating The Use of Banana Waste for Biogas Production in India. Master of Science Thesis. School of Engineering Department of Offshore, Process and Energy Engineering. Cranfield University.

Pakarinen, O., Lehtomäki, A. dan Rintala, J. (2008). Batch dark fermentative hydrogen production from grass silage: The effect of inoculum, $\mathrm{pH}$, temperature and VS ratio. International Journal of Hydrogen Energy 33(2): 594-601.

Regional Agronomist. (2007). Corn Stover as an Emergency Feed Source and the Potential for a Supplemental PAN Allowance for Small Grain Sown After Stover Removal. North Carolina Department of Agricultural and Consumer Service (NCDA and CS). USA.
Rubia, M.A.D., Fernández-Cegrí, V., Raposo, F. dan Borja, R. (2011). Influence of particle size and chemical composition on the performance and kinetics of anaerobic digestion process of sunflower oil cake in batch mode. Biochemical Engineering Journal 58-59: 162-167.

Schmidt, D. (2005). Anaerobic Digestion Overview. University of Minnesota - Extension, Department of Biosystem and Agricultural Engineering. Minnesota, USA.

U.S. DOE. (2001). Corn Stover for Bioethanol-Your New Cash Crop. National Renewable Energy Laboratory, US. Department of Energy. Washington, DC. USA.

Waish, J.L., Ross, C., Smith, M.S., Harper, S.R. dan Allen, W. (1988). Handbook on Biogas Utilization. Atlanta, Georgia: The Environment, Health, and Safety Division. Georgia Tech Research Institute.

Walch, E., Zemann, A., Schinner, F., Bonn, G. dan Bobleter, O. (1992). Enzymatic saccharification of hemicellulose obtained from hydrothermally pretreated sugar cane bagasse and beech bark. Bioresource technology 39(2): 173-177.

Wang, G. dan Schmidt, J.E. (2010). Biogas Production from Energy Crops and Agriculturalresidues: A Review. Information Service Department Risø National Laboratory for Sustainable Energy. Technical University of Denmark.

Wang, G., Gavala, H.N., Skiadas, I.V. dan Ahring, B.K. (2009). Wet explotion of wheat straw and codigestion with swine manure: effect of methane productivity. Waste Management 29: 2830-2835

Zhang, R. dan Zhiqin, Z. (1999). Biogasification of rice straw with an anaerobic-phased solids digester system. Bioresource Technology 68: 235-245.

Zhang, B., Zhang, L.L., Zhang, S.C., Shi, H.Z. dan Cai, W.M. (2005). The influence of $\mathrm{pH}$ on hydrolysis and acidogenesis of kitchen wastes in two-phase anaerobic digestion. Environ Technology 26(3): 329-339.

Zhao, Q., Leonhardt, E., MacConnell, C., Frear, C. dan Chen, S. (2010). Purification Technologies for Biogas Generated by Anaerobic Digestion. Climate Friendly Farming, CSANR Research Report. Hal. 1-24. 